\title{
Competence of Health Promotion Officers at Public Health Center (Puskesmas) in Empowering Integrated Health Service Post (Posyandu) Cadres in Aru Island District
}

\author{
Richard Alex Romroma ${ }^{1 *}$, Suriah ${ }^{1}$, Nurhaedar Djafar ${ }^{2}$, Muhammad Syafar ${ }^{1}$, Stang $^{3}$, Syamsiar S. Russeng ${ }^{4}$ \\ ${ }^{1}$ Department of Health Promotion, Faculty of Public Health, Hasanuddin University, Indonesia \\ ${ }^{2}$ Department of Nutrition, Faculty of Public Health, Hasanuddin University, Indonesia \\ ${ }^{3}$ Department of Reproductive Health, Faculty of Public Health, Hasanuddin University, Indonesia \\ ${ }^{4}$ Department of Occupational Health and Safety, Faculty of Public Health, Hasanuddin University, Indonesia
}

DOI: $10.36348 /$ sjnhc.2020.v03i11.002

| Received: 26.10.2020 | Accepted: 03.11.2020 | Published: 06.11.2020

*Corresponding author: Richard Alex Romroma

\section{Abstract}

Health promotion officers at Public health center need to have competition in implementing and managing health promotion programs. This study aims to determine the competence of health promotion officers at Public health center in the aspect of empowering Posyandu cadres for toddlers in Aru Islands District. This research is a qualitative research with a case study approach. The informants in the study were thirteen people who have criteria as main informants and supporting informants. The informants are determined using purposive sampling technique. Data were collected using in depth interviews, FGD (Focus Group Discussion), document review, observation and data were analyzed using constant comparison methods. The results showed that the ability of health promotion officers at the Public health center, both with a background in health promotion education and a non-health promotion background, in the process of empowering Posyandu cadres for the awareness stage of toddlers, have not been able to grow and increase awareness of cadres because activities are still limited to refreshing cadres once a year, guidance and direction to cadres by involving cross programs at the Public health center. There is a need for training and technical guidance for health promotion officers at Public health center to empower Posyandu cadres.

Keywords: Competence, Health promotion officer, Public health center, Empowerment of Posyandu cadres.

Copyright () 2020 The Author(s): This is an open-access article distributed under the terms of the Creative Commons Attribution 4.0 International License (CC BY-NC 4.0) which permits unrestricted use, distribution, and reproduction in any medium for non-commercial use provided the original author and source are credited.

\section{INTRODUCTION}

Health promotion is an effort to improve the capacity of the community through learning from, by, for and with the community, so that they can help themselves, and develop community-based activities, according to local socio-culture and supported by health-minded public policies [7]. Public health promotion personnel at Public health center are assigned the task of handling public health promotion programs at Public health center. Part of the main duties of the Public health center are to carry out public health efforts in the working area of the Public health center and carry out community health coaching [5].

To carry out their duties, health promotion officers at the Public health center must have the competence in accordance with their duties. Health promotion officers at Public health center need to understand very much competence in carrying out their duties and responsibilities. Competence is the characteristics and work ability that includes aspects of knowledge, skills, and attitudes according to the job and/or function of the position.

Every society must have power, but sometimes they are not aware, or this power is still not explicitly known. Power is understood as an ability that should be possessed by the community, so that they can do something (development) independently. Whereas empowerment is a gradual process that must be carried out in order to obtain and increase power so that people can be independent [11].

Several studies on the competence of health extension workers include research by Gamrin et al., [6] at the Maros District Health Office and Yuniarti [12] at the Pati District Health Office, showing that the ability of public health educators in health promotion practices is still lacking as a result of low knowledge. experience and skills. 
Aulia research in Makassar City [1] found the same thing, namely the ability to analyze targets or determine priorities, determine identity and evaluate extension activities of health promotion officers still need to be improved. Meanwhile, the ability to use extension media / tools and extension methods is considered good. Likewise, the results of research conducted by Hendrayani in Gowa District [9], found that the ability to analyze the capacity building stage of the Promokes officer was not optimal. The competence of health promotion officers for community empowerment is not maximal.

In Aru Islands, Maluku Province, there are 30 health centers and each health center has a special health promotion officer. From the initial data obtained only 2 officers with the first health extension functional positions and had attended training and training for health extension functional positions, the others (28 officers) with a non-health promotion education background, causing the implementation of health promotion at the health center has not been carried out properly. From the District Health Profile data for the last three years [2-4] obtained, it shows that there are several programs whose coverage is still low, such as under-fives being weighed, infant immunization coverage, the total Posyandu coverage of $63.40 \%$ is at the Primary strata, $28.5 \%$ for Intermediate and $7.3 \%$ for Purnama strata [4].

The district-level Posyandu cadre training for toddlers in 2015 was carried out, which involved cadres from each village and sub-district. Every year the posyandu cadre refreshing activity is carried out by each Puskesmas in its working area by utilizing Public health center Health Operational Assistance funds. However, the results of the service program coverage at the posyandu are still low. In several Public health center there were changes in health promotion program managers that were too fast, reports were often late and there was no special training for managers of health promotion programs.

\section{MATERIALS AND METHODS}

\section{Location and time of research}

This research was conducted at 30 Public health center in Aru Islands District. This research was conducted in April - August 2020.

\section{Types of Research}

This type of research is qualitative research with a case study approach.

\section{Research Informants}

The informants in this study were thirteen people who have the criteria as main informants and supporting informants. Informants were determined using purposive sampling technique.

\section{Data Collection}

Data collection methods used in this study were in-depth interviews, Focus Group Discussion (FGD), observation and document review.

\section{Data Analysis}

The data obtained through in-depth interviews in this study were analyzed using Constant Comparison analysis. This analysis technique is a technique used to compare events that occur when the researcher analyzes these events and is carried out continuously throughout the study.

\section{RESULT}

The Process of Empowering Posyandu Cadres for Toddlers is Carried Out by Health Promotion Officers at the Public Health Center.

Table-1: The Comparison Matrix of Posyandu Cadre Empowerment Processes carried out by health promotion officers at Public Health Center with a health promotion education background and a non-health promotion education background, at the awareness stage

\begin{tabular}{|l|l|l|}
\hline Informant & $\begin{array}{l}\text { Educational } \\
\text { Background }\end{array}$ & $\begin{array}{l}\text { The Process of Empowering Posyandu Cadres by Health Promotion } \\
\text { Officers at the Awareness Stage }\end{array}$ \\
\hline WAP & Health promotion & $\begin{array}{l}\text { Provide assistance to cadres every time, before the Posyandu opens and } \\
\text { provide direction }\end{array}$ \\
\hline SW & Health promotion & Perform cadre refreshing activities by involving cross-programs \\
\hline AR & Ners & Perform cadre refreshing activities \\
\hline
\end{tabular}

Table-1 shows an overview of informants with a background in health promotion education conducting activities to empower toddlers Posyandu cadres at the awareness stage with various forms of activities, including providing assistance and direction to cadres and conducting refreshing by involving cross-sector and cross-service programs at the Public health center. Meanwhile, the cadre empowerment process carried out by health promotion officers at the Public health center with educational background not health promotion only conducts cadre refreshing activities once a year.

Results of a Focus Group Discussion with Posyandu Cadres Regarding the Competence of Health Promotion Officers at the Public Health Center in Empowering Toddler Posyandu Cadres. 
Table-2: Results of FGD for Posyandu Cadres on Competence Public Health Center Health Promotion Officer in Empowering Toddler Posyandu Cadres in Aru Islands District

\begin{tabular}{|l|l|l|}
\hline No & $\begin{array}{l}\text { Cadre } \\
\text { Posyandu }\end{array}$ & Information from the Cadre of the Awareness stage \\
\hline 1. & AFG & Counseling at Posyandu, Participating in cadre refreshing activities \\
\hline 2. & FR & $\begin{array}{l}\text { There is no joint meeting at the Posyandu, but counseling is related to diseases before and after } \\
\text { weighing }\end{array}$ \\
\hline 3. & AK & There is counseling, there are discussions with one or two officers with cadres \\
\hline 4. & BH & Counseling, directing cadres to remain active \\
\hline 5. & FT & Often counseling at Posyandu, for cadres is directed to work at Posyandu \\
\hline 6. & JN & $\begin{array}{l}\text { There has never been an evaluation, when there is an impact of the disease, then information is } \\
\text { given }\end{array}$ \\
\hline 7. & AN & Education about disease \\
\hline
\end{tabular}

Table-2 shows the results of the FGD (Focus Group Discussion) with Posyandu cadres that the Posyandu cadre empowerment activities carried out by Public health center health promotion officers at the awareness stage are generally conducting training and refreshing cadres and also counseling at Posyandu, including 4 cadres who stated that they participated in refreshing activities and training for cadres as well as discussions on cadre activeness, 2 cadres stated that there was no joint meeting and evaluation, and 1 cadre stated that only counseling activities about disease.

\section{DISCUSSION}

Community empowerment in the health sector aims to raise awareness, knowledge, and understanding of the health of individuals, groups and communities, as well as generate a will which is a tendency to take an action or attitude to improve their health. Based on the results of research conducted on 13 informants in Aru Islands District, it shows that the awareness stage is a core part of the initial community empowerment and is the most important process in providing benefits to clients / targets. At this stage the client / beneficiary who wants to be empowered is "given enlightenment" by exploring, stimulating, not lecturing, but providing awareness that they have the right to have "something" [10] With a touch of awareness, it will further open people's desires and awareness about their current condition, so that they will be able to stimulate their awareness of the need to improve conditions to create a better future.

According to Notoatmodjo [8], knowledge and awareness of ways to maintain and improve health is the beginning of health empowerment which is the initial stage of the emergence of abilities, because ability is the result of the learning process. Thus the community is more open and feels they need knowledge and skills to improve conditions [11]. The awareness stage in this study was how the informants carried out the process to make Posyandu cadres aware that they had problems regarding the cadre's duties, the causes of the problems, their potential to overcome them, and to overcome problems and want to solve problems with the efforts they could do.
The results of the interviews the researchers conducted with informants related to the empowerment of Posyandu cadres at the awareness stage were basically still limited to the cadre refreshing activities which were carried out once a year and providing guidance and direction to cadres by involving crossprograms at the Public health center. Based on the informants' answers, it was not clear that there was an effort to make Posyandu cadres aware that they had problems with their duties as cadres and to know about the causes of these problems and to motivate cadres about their potential to overcome problems by facilitating or mentoring cadres.

The cadre refreshing activity which was carried out by the informants once a year did not have much impact on increasing awareness of cadres. Sulaeman [10] states that the process of empowering cadres is a relatively continuous process throughout the life of the cadre's experience and is not something that stops at a time. The results of this study indicate that 3 informants carried out the awareness stage only limited to coaching, mentoring and refreshing cadres. This is due to the lack of knowledge possessed by health promotion officers about cadre empowerment. and have never attended training on health promotion, especially training on the ability to conduct community empowerment.

\section{CONCLUSION}

The results showed that the ability of health promotion officers at the Public health center, both with a background in health promotion education and a nonhealth promotion background in the empowerment process of awareness-stage Posyandu cadres for toddlers in the awareness stage, was not able to grow and increase awareness of cadres because the activity was still limited to refreshing cadres once a year, guidance and direction to cadres by involving crossprograms at the Public health center. There is a need for training and technical guidance for health promotion officers at Public health center to empower Posyandu cadres. 


\section{REFERENCES}

1. Aulia, A. D. (2017). Kompetensi Penyuluhan dari Petugas Promosi Kesehatan Di Wilayah Kota Makassar. Tesis: Universitas Muslim Indonesia.

2. Dinas Kesehatan Kabupaten Kepulauan Aru. (2017). Profil Kesehatan Kabupaten Kepulaun Aru Tahun 2017. Indonesia.

3. Dinas Kesehatan Kabupaten Kepulauan Aru. (2018). Profil Kesehatan Kabupaten Kepulaun Aru Tahun 2018. Indonesia.

4. Dinas Kesehatan Kabupaten Kepulauan Aru. (2019). Profil Kesehatan Kabupaten Kepulaun Aru Tahun 2019. Indonesia.

5. Departemen Kesehatan, R. I. (2018). Keputusan Menteri Kesehatan RI. Nomor 585/MENKES/SK/V/2007 tentang Pedoman Pelaksanaan Promosi Kesehatan di Puskesmas. Indonesia.

6. Gamrin B., Thaha R. M., \& Naiem, M. F. (2014). Kemampuan Penyuluh Kesehatan Masyarakat Terhadap Cakupan Program Promosi Kesehatan di
Kabupaten Maros. Jurnal Kesehatan Masyarakat. 2(5):200-208.

7. Kemenkes, R. I. (2013). Modul Pelatihan Pengangkatan Pertama Jabatan Fungsional Penyuluh Kesehatan Masyarakat Ahli. Pusat Promosi Kesehatan Bekerja Sama dengan Pusdiklat Aparatur Kemkes RI. Indonesia: Kementerian Kesehatan Republik Indonesia.

8. Notoatmodjo. (2007). Promosi Kesehatan dan Ilmu Perilaku. Rineka Cipta : Jakarta.

9. Hendrayani, S. (2018). Kompetensi Petugas Promosi Kesehatan Untuk Pemberdayaan Masyarakat Dalam Program Gerakan Masyarakat Hidup Sehat (GERMAS) Di Kabupaten Gowa. Tesis : Universitas Hasanuddin.

10. Sulaeman E. S. (2016). Pemberdayaan Masyarakat Di Bidang Kesehatan (Teori dan Implementasi). Gadjah Mada University Press.

11. Sulistiyani A. T. (2017). Kemitraan dan ModelModel Pemberdayaan. Gava Media : Yogyakarta.

12. Yuniarti. (2012). Kinerja Petugas Penyuluh Kesehatan Masyarakat Dalam Praktik Promosi Kesehatan di Dinas Kesehatan Kabupaten Pati. 